\title{
A FRESH LOOK AT THE HEALTH-WEALTH CORRELATION: A CASE STUDY OF EUROPEAN COUNTRIES
}

October 2019

TERESA GARCI A- MUÑOZ

SHOSHANA NEUMAN

TZAHI NEUMAN 


\title{
A FRESH LOOK AT THE HEALTH-WEALTH CORRELATION: A CASE STUDY OF EUROPEAN UNION
}

\author{
CELSI Discussion Paper No. 52 \\ october 2019
}

\section{Teresa García-Muñoz}

University of Granada, Spain

CELSI, SIOVakia

\section{Shoshana Neuman}

The Academi c Ashkelon College

CELSI, SI ovakia

\section{Tzahi Neuman}

Hadassah-Hebrew University Medical

Center

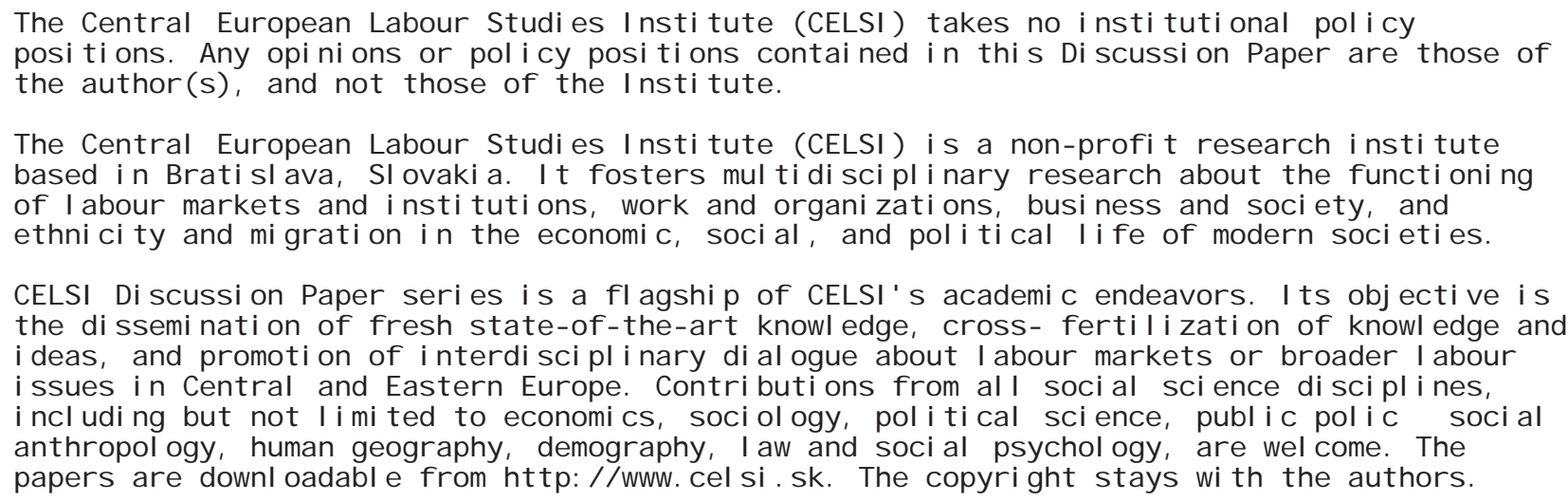

Central European Labour Studies Institute (CELSI) 
CELSI Discussion Paper No. 52

October 2019

\section{ABSTRACT}

\section{A Fresh Look at the Health-Wealth Correlation: A Case Study of European Countries}

This paper contributes to the development-health literature by studying the correlation between development measures (see below) and health measures. one subjective ('self-assessed-health-status'), and the other one objective (the individual's 'number of chronic diseases'). Correlations are examined for 29 European countries, using the SHARE data set, and country-level development measures. Specifically, we examine whether country fixedeffects in regressions of health measures, controlling for individual socio-demographic variables, are significantly correlated with country development variables, which include: logarithm of per-capita GDP; the Human Development Index; the Social progress Index; I fe expectancy; percentage of GDP spent on health; and the novel measure expressed by the Environmental Health Index. The novelty of our study is the introduction of a channel for the significant health-wealth correlation, speculating that the driving forces are psychological.

Keywords: development; self-assessed-health-status; diseases; environmental hazards; psychological motives; SHARE; Europe JEL Classification: 11 ; 115

\section{Corresponding Author:}

Teresa García-Muñoz

University of Granada, Spain

CELSI, SI ovakia

tgarciam@ugr.es 


\section{A Fresh Look at the Health-Wealth Correlation: A Case Study of European Countries}

\section{Introduction and motivation}

The direction of causality between health and economic development of states is not clear (Smith, 1999). Some literature indicates that the population's health-status affects the level of economic development (WHO, 2001; Bloom et al., 2004; Acemoglu \& Johnson, 2007; Deaton, 2007). But on the other hand, studies also show that causality can run in the opposite direction: from the country's economic status to health of the population (Ruhm, 2000, 2006, 2008; Subramanian et al., 2002; Olsen \& Dahl, 2007; Ploubidis et al., 2012).

In this study, we use an intuitive methodology, presented in Oswald and $\mathrm{Wu}$ (2010), and published in Science, to test whether country-specific aggregate health levels are correlated with country measurements of development and wealth. Specifically, we examine whether country fixed-effects in health regressions, controlling for individual socio-demographic variables, are significantly correlated with a battery of country macrovariables.

As health measurements we use two alternative variables: self-assessed-health-status (SAHS); and, the 'number of chronic diseases' that the respondent was diagnosed with. While the two variables are self-reported by the respondent - only the first one is subjective and based on the individual's perception of his health status, while the other one is based on more objective health dimensions, determined by the individual's medical care-givers.

The country-specific macro variables that are used include: logarithm of per-capita GDP; the Human Development Index (HDI); the Social Progress Index (SPI); life expectancy at birth; percentage of GDP spent on health (per capita); and an Environmental Health Index that relates to three categories of environmental concern: air quality, water and sanitation quality, and prevalence of toxic heavy metals (in water, soil, food). This Index is quite novel in development-health studies, and is added, given the increased environmental concern. It is now well established that environmental hazards create 
market externalities and other market dysfunctions, and thus negatively affect development (e.g., Trasande, 2019). ${ }^{1}$

The very rich data base, derived from the Survey of Health Aging and Retirement Europe (SHARE), is used for the empirical analysis. SHARE is a multidisciplinary and crossnational panel data set of micro data on health, socio-demographic status, and social and family networks, that includes tens of thousands of individuals aged 50 or over. ${ }^{2}$ SHARE has a balanced representation of the various regions in Europe, ranging from Northern countries (Denmark, Sweden, Finland, Ireland, Lithuania, and Latvia), through Central Europe (Austria, France, Germany, Switzerland, Belgium, the Czech Republic, Luxembourg, and the Netherlands), through Eastern Europe (Poland, Hungary, Slovenia, Croatia, Estonia, Bulgaria, Romania, and Slovakia), to the South (Spain, Italy, Greece, Malta, Cyprus, and Portugal). Israel is also included in some of the waves. SHARE has a wealth of data on personal characteristics that are not commonly found in other data sets (e.g., risky behaviors like obesity; household wealth; occupational status; cognitive skills; information on parents - whether alive or not). This diversity of variables allows us to control for a variety of personal socio-demographic determinants, and use measurements related to objective and to subjective health of the sampled individuals.

The empirical analysis includes 2 layers: (a) estimation of regression equations for the two health variables, using a set of personal characteristics as explanatory variables, and including dummy variables for countries. The coefficient values of these dummy variables represent the country aggregate health differences (vis-à-vis the reference country); (b) the second layer, presents the correlations between these country-level health differences - once individuals' characteristics have been controlled for - and objective country-specific aggregate macroeconomic development variables, listed above.

The statistical analysis that is employed follows Oswald and $\mathrm{Wu}$ (2010). In their paper

\footnotetext{
1 Trasande (2019) is also documenting the economic costs of failing to prevent diseases of environmental origin. For instance, disease cost due to endocrine disrupting chemicals, in the United States and Europe, are estimated at 340 billion dollar and 163 billion dollar, respectively.

2 The SHARE data base includes individuals aged 50 and over, which means that our correlations are tested for the older populations. It follows that the results need to be generalized also for younger populations (see discussion of results). On the other hand, as the share of the older sub-population is constantly growing in virtually all countries - understanding its health determinants has important policy implications.
} 
Oswald and $\mathrm{Wu}$ (2010) used a sample of US states to investigate correlations between state-level subjective-well-being (estimated using state dummies in a subjective-wellbeing equation) and objective state measures. We borrow their technique and twist it into the health arena, using - as our units of analysis - European countries rather than US states.

The primary motivation for the paper is a careful statistical analysis of the correlation between health and development in European states. We, however, also have another major goal, which is an attempt to establish the channel that connects development and health, speculating that psychological elements are at work. In order to explore this potential path, we are experimenting with three indirect approaches: (i) replication of the statistical analysis with two alternative measures of health - a subjective-health measure (self-assessed-health-status), and a more objective one ('number of diseases that the respondent has been diagnosed with'). If psychological elements constitute the main driving forces behind the correlation between development and health (e.g., residents of more developed countries feel more protected and trust the country health system to provide good medical care in case of need), we would expect Hypothesis 1: more pronounced correlations between development measures and the subjective-health measure, compared to correlations between development and an objective health measure; (ii) decomposing the sample by immigration status - with separate regressions for natives and immigrants. The perception that a better development level in the country of residence leads to better health, due to better health-care facilities (and consequently to a statement of better subjective-health), seems to be established among native residents and much less prevalent among immigrants. This leads to Hypothesis 2: healthdevelopment correlations will be more pronounced and significant within the sample of natives, than within the immigrants' sample; (iii) in a similar vein, the immigrants' sample is further decomposed by years-since-migration, distinguishing between immigrants who live in the receiving country 33 years or less, and immigrants who have tenure of more than three decades. Focusing on the sub-group of more recent immigrants, we hypothesize that within this sub-group - the correlation of subjective-health with development indices will further decline - leading to lower and less significant (or insignificant) correlation coefficients. We therefore arrive at Hypothesis 3: within the 
immigrants' sample - the health-wealth correlations will be lower (and insignificant) for immigrants who reside in the receiving country three decades or less, compared to immigrants with more years-since-migration. ${ }^{3}$ Support for these three hypotheses will lend support to the conjecture that the health-development correlation has psychological roots.

The structure of the paper is the following: The next section describes the variables used for the econometric analysis. Section 3 presents the empirical analysis of (a) the determinants of health; and (b) the correlations between country health coefficients and country-specific development variables. Section 4 summarizes and concludes.

\section{Variables used for the econometric analysis}

This study used data from SHARE Waves 1, 2, 4, 5, 6, and 7. Wave 3 was different and included background retrospective data; See Börsch-Supan (2018a-e; 2019) for methodological details. In order to increase the country sample sizes, all waves were pooled. To avoid repeated observations for the same individual (if she/he participated in more than one wave) - we included in the pooled sample only one observation per individual. For individuals who participated in more than one wave of the SHARE survey, only data of her/his most recent participation has been included in the sample. After the removal of individuals with missing observations (on any of the study variables), the sample consisted of 105,857 individuals, in 29 countries.

The two alternative dependent variables used in the regression analyses are:

- SAHS (self-assessed-health-status): SHARE includes the following question, related to the respondent's subjective-health: "Would you say that your current health is: 1. Excellent; 2. Very Good; 3. Good; 4. Fair; 5. Poor”. We rescaled the categories of the SAHS question, with the first category indicating 'Poor' health, and the last category indicating 'Excellent' health. The average of the SAHS score, for the whole sample, is 2.76 .

\footnotetext{
${ }^{3}$ An alternative explanation for the stronger health-wealth correlation within immigrants who stay in the host country for two decades or more, compared to more recent immigrants - could be that immigrants' health-status improves with time-since-migration. However, extensive evidence for many countries indicates that this is not the case. On the contrary: upon arrival immigrants tend to be healthier that natives, and with time-since-migration their health deteriorates (e.g., Neuman, 2014, Constant et al., 2018).
} 
Questions on subjective health are now commonly introduced in questionnaires used within the social sciences and the medical professions. In most questionnaires, respondents are asked to assess their health-status by rating their overall health on a 5-10 scale.

Obviously, the subjective health-status measurements could suffer from biases, due to respondents' differential perceptions on health (Bago d'Uva et al., 2008), and due to cultural differences between countries in health perceptions (Jürges, 2007). The use of health-related vignettes (Salomon et al., 2004) could reduce the reporting errors related to subjective-health. Unfortunately, few examples are found in the literature where subjective-health measurements are corrected using this method. Probably, this is due to the lack of appropriate anchoring vignettes. This is the case also with our data. On the other hand, the use of self-rated health seems to also have advantages, and is increasingly used in empirical research. A person's own understanding of her/his health is the 'internal' view of health, as opposed to 'external' views that are based on observations of doctors or pathologists (Sen, 2002). The external view of health has come under considerable criticism, particularly from anthropological perspectives, for taking a distanced and less sensitive view of illness and health (Kleinman, 1988, 1995). The belief that the individual is the best evaluator of her/his health status is supported by the findings of numerous studies, which indicate that self-ratings of health are good predictors of mortality and morbidity, even more than medical records (e.g., Mora et al., 2008).

- Number of chronic diseases: Respondents were asked "Has a doctor ever told you that you had/have...?", followed by a list of diseases: a heart attack; high blood pressure or hypertension; high blood cholesterol; a stroke or a cerebral-vascular disease; diabetes or high blood sugar; chronic lung disease; cancer or a malignant tumor; stomach, duodenal or peptic ulcer; Parkinson disease; cataracts; hip fracture or femoral fracture. The variable 'number of chronic diseases' is defined as the total number of the above-listed diseases that the respondent was diagnosed with. The average of chronic diseases, for the whole sample, is 1.23. 
As an illustration, Table 1 presents proportions of respondents who declare having 'poor' health, proportions of respondents with 'excellent' health, and average number of chronic diseases. These descriptive statistics are calculated for four out of the 29 sampled countries: two countries with high per-capita GDP (Switzerland and The Netherlands), and at the other end, two countries with low per-capita GDP (Poland and Hungary).

As is evident from Table 1, there are substantial differences in the two dimensions of health, between the two groups of countries. These raw country differences could stem from differences in personal socio-demographic conditions, and also from macroeconomic country-level differences. In the second part of study, once individual effects have been controlled for, we will test whether the country-level health differences are correlated with country-specific macro development variables.

Table 1: Percentages and averages of subjective/objective health measures, in four countries (pooled samples - 2004-2017)

\begin{tabular}{rccc}
\hline \hline & $\begin{array}{c}\text { Percentage } \\
\text { with 'poor' } \\
\text { health }\end{array}$ & $\begin{array}{c}\text { Percentage } \\
\text { with 'excellent' } \\
\text { health }\end{array}$ & $\begin{array}{c}\text { Average } \\
\text { number of } \\
\text { chronic } \\
\text { diseases }\end{array}$ \\
\hline \hline The Nehterlands $(\mathrm{N}=5,356)$ & 4.9 & 12.3 & 0.966 \\
Switzerland $(\mathrm{N}=3,726)$ & 4.9 & 10.1 & 0.877 \\
Poland $(\mathrm{N}=5,454)$ & 21.3 & 1.5 & 1.363 \\
Hungary $(\mathrm{N}=1,867)$ & 19.6 & 2.9 & 1.366 \\
\hline \hline
\end{tabular}

Table 2 presents definitions of the explanatory variables used in the regression analyses. They are divided into several categories: (i) Socio-demographic variables, where, among, other variables, we include two dummies marking if mother and father are alive, as proxies of 'good genetics'; and a dummy variable indicating the individual's immigration status. $=1$ if she/he is an immigrant; (ii) behavioral risk variable (e.g., over-eating leading to obesity), as proxy of lifestyle aspects; (iii) memory abilities variable - to take into account individuals' cognitive health; (iv) wave controls; and (v) country dummyvariables. Appendix Table A.1 summarizes the descriptive statistics of all research variables. 
Table 2: Variable definitions

(i) Socio-demographic variables

Immigrant Dummy variable that is set to 1 for immigrants

Female Dummy variable that is set to 1 for female respondents

Age Three dummy variables, relating to age groups of: 61-to-70; 71to- $80 ; 81$ and over; with the reference group being age of 50 -to60

Education Dummy variable that equals 1 if the respondent completed the first and/or the second stage of tertiary education (using the International Standard Classification of Education, ISCED-97 classification). The ISCED was designed by UNESCO to serve as an instrument for internationally comparable education statistics

Marital status Two dummy variables: married (or cohabitating); and widowed; with the reference group including: divorced, separated and single

Living parents Two dummy variables: Mother/father alive

Difficulties to Dummy variable that equals 1 if the respondent's household has make ends meet financial difficulties: indicated by a positive response to the option "makes ends meet with great difficulty"

Current Five dummy variables: retired; employed; homemaker; sick and occupational other job situations (living off own property, student, employed status in voluntary work); with the reference group - unemployed

(ii) Behavioral risk factor

Obese Dummy variable that is equal to 1 if the Body Mass Index (BMI, based on weight and height) is greater than 30

(iii) Memory/cognitive skills

Recall of words Continuous variable that is the number of words that the individual recalled from a list of 10 words. Based on the following question: "Now, I am going to read a list of words from my computer screen. We have purposely made the list long so it will be difficult for anyone to recall all the words. Most people recall just a few. Please listen carefully, as the set of words cannot be repeated. When I have finished, I will ask you to repeat as many words as you can, in any order"

(iv) Wave dummy variables 


\begin{tabular}{ll}
\hline \multicolumn{1}{c}{ Wave $i$} & Dummy variable $=1$ if the individual belongs to wave $i, i=1,2$, \\
$4,5,6,7$
\end{tabular}

\section{Empirical analysis and findings}

The empirical analysis has 2 layers: (a) estimation of health equations for the two dimensions of health, using the explanatory variables described above, with special focus on the country (fixed-effects) dummy variables, that reflect country aggregate health deviations from the health level of the reference country, that is Austria; and (b) estimation of correlations between the country health dummy variables, and the following six macro country development measures: logarithm of per-capita GDP; the Human Development Index (HDI); the Social Progress Index (SPI); life expectancy at birth; percentage of GDP spent on health; and an Environmental Health Index (definitions follow in section 3.2 below).

\subsection{Regression equations: Determinants of 'subjective-health', and 'chronic diseases'}

The health dependent variable 'chronic diseases' is continuous. It is therefore natural to use Ordinary Least Squares (OLS) regressions to estimate health determinants. Since reported subjective-health (SAHS) is intrinsically ordinal (with 5 values of 1-5), the natural way to estimate a SAHS equation is by using Ordered Logit or Ordered Probit. However - as discussed in Clark and Senik (2011) - when the dependent variable relates to satisfaction scores, the use of a linear model instead of an Ordered Logit Model does not change the basic results. The simpler OLS method also allows coefficients to be read off as cardinal subjective-health scores. Experimenting with Ordered Logit regressions resulted in minor changes (in terms of sign, magnitude, and significance of coefficients available from the authors upon request), we therefore preferred to present the results of the OLS regression, also for the SAHS equation. 
Table 3 and 4 present the OLS regression results for a pooled sample of waves 1, 2, 4, 5, 6 and 7 of SHARE, with 'self-assessed-health-status' and 'number of chronic diseases' as dependent variables, respectively. In both Tables results are presented also for the separate sub-samples of natives and immigrants.

Table 3: Determinants of self-assessed-health-status (SAHS), pooled sample - 20042017

\begin{tabular}{cccc}
\hline Variables & $\begin{array}{c}\text { Model 1 } \\
\text { whole sample } \\
\text { coefficients } \\
\text { (standard error) }\end{array}$ & $\begin{array}{c}\text { Model 2 } \\
\text { natives } \\
\text { coefficients } \\
\text { (standard error) }\end{array}$ & $\begin{array}{c}\text { Model 3 } \\
\text { immigrants } \\
\text { coefficients } \\
\text { (standard error) }\end{array}$
\end{tabular}

(i) Socio-demographic personal variables

\begin{tabular}{|c|c|c|c|}
\hline Immigrant & $-0.074(0.018)^{* * *}$ & & \\
\hline Female & $-0.046(0.006)^{* * *}$ & $-0.046(0.006)^{* *}$ & $-0.050(0.036)$ \\
\hline \multicolumn{4}{|l|}{ Age (years) } \\
\hline $50-60$ & Ref. & Ref. & Ref. \\
\hline $61-70$ & $-0.038(0.010)^{* * *}$ & $-0.039(0.010) * * *$ & $0.008(0.053)$ \\
\hline $71-80$ & $-0.249(0.012)^{* * *}$ & $-0.251(0.012)^{* * *}$ & $-0.193(0.066)^{* * *}$ \\
\hline 81 and over & $-0.453(0.014) * * *$ & $-0.456(0.014)^{* * *}$ & $-0.306(0.080)^{* * *}$ \\
\hline High education & $0.142(0.008)^{* * *}$ & $0.143(0.008)^{* * *}$ & $0.125(0.040)^{* * *}$ \\
\hline \multicolumn{4}{|l|}{ Marital status } \\
\hline Single/Divorced/Separated & Ref. & Ref. & Ref. \\
\hline Married & $0.055(0.008)^{* * *}$ & $0.056(0.008)^{* * *}$ & $0.029(0.040)$ \\
\hline Widowed & $0.012(0.011)$ & $0.016(0.011)$ & $-0.114(0.063)^{*}$ \\
\hline \multicolumn{4}{|l|}{ Parents alive } \\
\hline Mother & $0.095(0.008)^{* * *}$ & $0.093(0.008)^{* * *}$ & $0.148(0.044)^{* * *}$ \\
\hline Father & $0.112(0.011)^{* * *}$ & $0.114(0.012)^{* * *}$ & $0.057(0.063)$ \\
\hline Difficulties to make ends meet & $-0.314(0.010)^{* * *}$ & $-0.315(0.010)^{* * *}$ & $-0.309(0.046)^{* * *}$ \\
\hline \multicolumn{4}{|l|}{ Current occupational status } \\
\hline Unemployed & Ref. & Ref. & Ref. \\
\hline Retired & $-0.040(0.021)^{*}$ & $-0.024(0.022)$ & $-0.269(0.091)^{* * *}$ \\
\hline Employed & $0.243(0.021)^{* * *}$ & $0.257(0.021)^{* * *}$ & $0.108(0.082)$ \\
\hline Homemaker & $0.022(0.023)$ & $0.033(0.023)^{* * *}$ & $-0.094(0.098)$ \\
\hline Sick & $-0.908(0.024)^{* * *}$ & $-0.893(0.025) * * *$ & $-1.098(0.098)^{* * *}$ \\
\hline Other & $-0.043(0.031)$ & $-0.032(0.032)$ & $-0.155(0.187)$ \\
\hline
\end{tabular}

(ii) Behavioral risks

\begin{tabular}{llll} 
Obese $(\mathrm{BMI}>30)$ & $-0.268(0.007)^{* * *}$ & $-0.268(0.007)^{* * *}$ & $-0.244(0.039)^{* * *}$ \\
\hline
\end{tabular}

(iii) Memory/cognitive skills

\begin{tabular}{lccc} 
Recall of words & $0.080(0.002)^{* * *}$ & $0.080(0.002)^{* * *}$ & $0.082(0.010)^{* * *}$ \\
\hline (iv) Wave dummy variables & Yes & Yes & Yes \\
\hline (v) Country of residence dummy & Ref. & Ref. & Ref.
\end{tabular}


Variables
Model 1

whole sample coefficients

(standard error)
Model 2

natives

coefficients

(standard error)
Model 3

immigrants

coefficients

(standard error)

\section{variables}

Austria

Germany

Sweden

$-0.282(0.019) * * *$

$-0.280(0.019)^{* * *}$

$0.220(0.021) *$

$* * *$

$-0.442(0.109)^{* * *}$

The Netherlands

$0.128(0.021)$

$0.134(0.022)$ *

$0.011(0.141)$

Spain

$-0.065(0.019) * * *$

$-0.064(0.019) * * *$

$-0.084(0.124)$

Italy

$-0.100(0.019)^{* * *}$

$-0.097(0.019)$

$0.118(0.156)$

France

$-0.140(0.018)^{* * *}$

$-0.138(0.019)$

$0.154(0.228)$

Denmark

$0.273(0.022) *$

$0.280(0.022)$

$-0.282(0.117)^{* *}$

Greece

$0.267(0.024)^{* * *}$

$0.273(0.024)$

$-0.296(0.216)$

Switzerland

$0.244(0.022)^{* * *}$

$0.248(0.022)$

$0.010(0.157)$

Belgium

$0.020(0.018)$

$0.021(0.018)$

$0.043(0.144)$

Israel

$0.059(0.032)$ *

$0.175(0.037)^{* * *}$ $-0.080(0.121)$

The Czech Republic

$-0.171(0.018)^{* * *}$

$-0.166(0.018)^{* * *}$

$-0.333(0.113)^{* * *}$

Poland

$-0.461(0.025)^{* * *}$

Ireland

$0.629(0.061)^{* * *}$

$-0.453(0.026)$

$-0.428(0.140)^{* * *}$

Luxembourg $\mathbf{- 0 . 0 2 4 ( 0 . 0 3 0 )}$

$0.652(0.064)^{* * *}$ $-0.422(0.156)^{* * *}$

\begin{tabular}{|c|c|c|c|}
\hline Luxembourg & $-0.024(0.030)$ & $-0.008(0.032)$ & $-0.249(0.123)^{* *}$ \\
\hline Hungary & $-0.444(0.037)^{* * *}$ & $-0.440(0.037) * * *$ & $-0.527(0.357)$ \\
\hline Portugal & $\mathbf{0 . 4 1 7}(0.033)^{* * *}$ & $-0.423(0.034)^{* * *}$ & $-0.117(0.230)$ \\
\hline Slovenia & $\mathbf{0 . 1 6 2}(0.020)^{* * *}$ & $-0.161(0.021)^{* * *}$ & $-0.238(0.143)^{*}$ \\
\hline Estonia & $\mathbf{0 . 6 5 9}(0.018)^{* * *}$ & $-0.655(0.018)^{* * *}$ & $-0.861(0.120) * * *$ \\
\hline Croatia & $\mathbf{0 . 2 3 1}(\mathbf{0 . 0 2 8})^{* *}$ & $-0.234(0.029)^{* * *}$ & $-0.309(0.143)^{* *}$ \\
\hline Lithuania & $-0.506(0.032)^{* * *}$ & $-0.491(0.033) * * *$ & $-0.750(0.144)^{* * *}$ \\
\hline Bulgaria & $-0.084(0.036)^{* *}$ & $-0.071(0.036)^{*}$ & $-0.155(0.371)$ \\
\hline Cyprus & $0.188(0.040)^{* * *}$ & $0.212(0.041)^{* * *}$ & $-0.472(0.222)^{* *}$ \\
\hline Finland & $-0.330(0.034)^{* * *}$ & $-0.315(0.034)^{* * *}$ & $-0.716(0.264)^{* * *}$ \\
\hline Latvia & $-0.695(0.032) * * *$ & $-0.705(0.034)^{* * *}$ & $-0.806(0.132) * * *$ \\
\hline Malta & $-0.022(0.039)$ & $-0.007(0.040)$ & $-0.266(0.226)$ \\
\hline Romania & $\mathbf{0 . 3 9 0}(0.034)^{* * *}$ & $-0.376(0.034) * * *$ & $\mathbf{0 . 8 3 1}(0.320)^{* * *}$ \\
\hline Slovakia & $0.120(0.033)^{* * *}$ & $0.137(0.034)^{* * *}$ & $-0.367(0.272)$ \\
\hline Constant & $2.636(0.030)^{* * *}$ & $2.628(0.031)^{* * *}$ & $2.883(0.142) * * *$ \\
\hline Sample Size & 105,857 & 102,487 & 3,370 \\
\hline
\end{tabular}

Notes: * significant at $0.10 ; * *$ significant at $0.05 ; * * *$ significant at 0.01 ; Robust standard errors 
Table 4: Determinants of 'number of chronic diseases', pooled sample - 2004-2017

Variables

\section{Model 1}

whole sample

coefficients

(standard error)
Model 2

natives

coefficients

(standard error)
Model 3

immigrants

coefficients

(standard error)

(i) Socio-demographic personal variables

Immigrant $0.041(0.023)^{*}$

Female $-0.072(0.008)^{* * *}$ $-0.072(0.008)^{* * *}$ $-0.088(0.046)^{*}$

Age (years)

50-60

Ref.

61-70

$0.203(0.011)^{* * *}$

Ref.

Ref.

71-80

$0.568(0.014)^{* * *}$

$0.198(0.011)^{* * *}$

$0.302(0.065)^{* * *}$

81 and over

$0.715(0.017)^{* * *}$

$0.563(0.014)^{* * * *}$

$0.674(0.086) * * *$

High education

$0.705(0.018)^{* * *}$

$0.953(0.111) * * *$

Marital status

Single/Divorced/Separated $-0.064(0.009)^{* * *}$ $-0.066(0.009)^{* * *}$ $-0.033(0.051)$

\section{Married \\ Widowed}

Ref.

Ref.

Ref. $0.024(0.010)^{* * *}$

$0.024(0.010)^{* *}$

$0.056(0.058)$

Parents alive

$0.092(0.014)^{* * *}$

$0.092(0.015) * * *$

$0.123(0.086)$

\section{Mother \\ Father}

$-0.103(0.009) * * *$

$-0.104(0.009) * * *$

$-0.078(0.051)$

$-0.101(0.011)^{* * *}$

$-0.103(0.011)$

$-0.068(0.062)$

Difficulties to make ends meet

$0.253(0.013)^{* * *}$

$0.258(0.014)^{* * *}$

$0.184(0.059)^{* * *}$

Current occupational status

Unemployed

Ref.

Retired

Ref.

Ref.

Employed

$0.266(0.022)^{* * *}$

$0.260(0.023)^{* * *}$

$0.293(0.093)^{* * * *}$

$-0.033(0.021)$

$-0.036(0.022)$

$-0.060(0.074)$

Homemaker

$0.160(0.025)^{* * *}$

$0.156(0.025)^{* * *}$

$0.161(0.104)$

Sick $0.725(0.031)^{* * *}$

$0.720(0.033)^{* * *}$

$0.746(0.124)^{* * * *}$

Other

$0.188(0.036) * * *$

$0.184(0.037) * * *$

$0.178(0.171)$

(ii) Behavioral risks

$$
\text { Obese (BMI>30) }
$$

$0.463(0.009)^{* * *}$

$0.462(0.009)^{* * *}$

$0.493(0.055)^{* * *}$

(iii) Memory/cognitive skills

$$
\text { Recall of words }-0.023(0.002)^{* * *}
$$

$-0.023(0.002)^{* * * *}$

$-0.016(0.012)$

(iv) Wave dummy variables

Yes

Yes

Yes

\section{(v) Country of residence dummy} variables

Austria

Ref.

Ref.

\begin{tabular}{|c|c|c|c|}
\hline Germany & $0.135(0.024)^{* * *}$ & $0.132(0.024)^{* * *}$ & $0.437(0.126)^{* * *}$ \\
\hline Sweden & $-0.033(0.025)$ & $-0.043(0.025)^{*}$ & $0.449(0.148) * * *$ \\
\hline etherlands & $-0.148(0.025)^{* * *}$ & $0.157(0.026)^{* * *}$ & $0.247(0.143)^{*}$ \\
\hline Spain & $0.008(0.024)$ & $0.003(0.024)$ & $0.114(0.171)$ \\
\hline Italy & $-0.041(0.023)^{*}$ & $-0.050(0.023)^{* *}$ & $-0.164(0.194)$ \\
\hline France & $-0.058(0.022)^{* *}$ & $-0.066(0.023) * * *$ & $0.354(0.133) * * *$ \\
\hline Denmark & $0.067(0.025)^{* * *}$ & $0.055(0.025)^{* *}$ & $0.958(0.300)^{* * *}$ \\
\hline
\end{tabular}

Ref. 


\begin{tabular}{|c|c|c|c|}
\hline Variables & $\begin{array}{c}\text { Model 1 } \\
\text { whole sample } \\
\text { coefficients } \\
\text { (standard error) }\end{array}$ & $\begin{array}{c}\text { Model 2 } \\
\text { natives } \\
\text { coefficients } \\
\text { (standard error) }\end{array}$ & $\begin{array}{c}\text { Model 3 } \\
\text { immigrants } \\
\text { coefficients } \\
\text { (standard error) }\end{array}$ \\
\hline Greece & $-0.023(0.029)$ & $-0.036(0.029)$ & $0.299(0.171)^{*}$ \\
\hline Switzerland & $-0.270(0.025)^{* * *}$ & $-0.273(0.025)^{* * *}$ & $-0.025(0.133)$ \\
\hline Belgium & $0.114(0.022)^{* * *}$ & $0.106(0.023)^{* * *}$ & $0.515(0.136)^{* * *}$ \\
\hline Israel & $0.337(0.041)^{* * *}$ & $0.257(0.046)^{* * *}$ & $0.863(0.130)^{* * *}$ \\
\hline The Czech Republic & $0.227(0.023)^{* * *}$ & $0.220(0.023)^{* * *}$ & $0.586(0.189)^{* * *}$ \\
\hline Poland & $0.076(0.032)^{* *}$ & $0.047(0.032)$ & $0.669(0.221)^{* * *}$ \\
\hline Ireland & $-0.001(0.071)$ & $-0.016(0.075)$ & $0.452(0.215)^{* *}$ \\
\hline Luxembourg & $0.171(0.037)^{* * *}$ & $0.171(0.040)^{* * *}$ & $0.568(0.140)^{* * *}$ \\
\hline Hungary & $0.116(0.049)^{* *}$ & $0.123(0.050)^{* *}$ & $-0.301(0.327)$ \\
\hline Portugal & $0.248(0.045)^{* * *}$ & $0.248(0.046)^{* * *}$ & $0.271(0.234)$ \\
\hline Slovenia & $0.065(0.025)^{* * *}$ & $0.062(0.026)^{* *}$ & $0.304(0.154)^{* *}$ \\
\hline Estonia & $0.022(0.024)$ & $0.011(0.025)$ & $0.583(0.184)^{* * *}$ \\
\hline Croatia & $0.120(0.033)^{* * *}$ & $0.111(0.034)^{* * *}$ & $0.607(0.155)^{* * *}$ \\
\hline Lithuania & $0.150(0.043)^{* * *}$ & $0.101(0.044)^{* *}$ & $1.025(0.193)^{* * *}$ \\
\hline Bulgaria & $-0.187(0.040)^{* * *}$ & $-0.220(0.041)^{* * *}$ & $0.096(0.267)$ \\
\hline Cyprus & $0.155(0.051)^{* * *}$ & $0.119(0.052)^{* *}$ & $0.912(0.330)^{* * *}$ \\
\hline Finland & $0.184(0.042)^{* * *}$ & $0.150(0.043)^{* * *}$ & $1.016(0.324)^{* * *}$ \\
\hline Latvia & $-0.187(0.044)^{* * *}$ & $-0.248(0.047)^{* * *}$ & $0.548(0.167)^{* * *}$ \\
\hline Malta & $-0.053(0.047)$ & $-0.084(0.048) *$ & $-0.006(0.528)$ \\
\hline Romania & $-0.367(0.040)^{* * *}$ & $\mathbf{0 . 4 0 1}(0.041)^{* * *}$ & $-0.498(0.409)$ \\
\hline Slovakia & $-0.430(0.038)^{* * *}$ & $-0.464(0.039) * * *$ & $-0.069(0.197)$ \\
\hline Constant & $0.691(0.034)^{* * *}$ & $0.703(0.035)^{* * *}$ & $0.228(0.151)$ \\
\hline Sample Size & 105,857 & 102,487 & 3,370 \\
\hline
\end{tabular}

Notes: $*$ significant at $0.10 ; * *$ significant at $0.05 ; * * *$ significant at 0.01 ; Robust standard errors

The pattern that emerges from Tables 3 and 4, for the whole sample, is the following ${ }^{4}$ : immigrants report lower levels of SAHS and more chronic diseases compared to natives ${ }^{5}$; females report lower levels of SAHS, and less chronic diseases compared to males; as expected, with the advancement of age, individuals report lower levels of SAHS and more chronic diseases; more educated individuals tend to report higher SAHS levels and

\footnotetext{
${ }^{4}$ The regression coefficients represent weighted average effects across the different countries. It could well be the case that the effects are different by country (e.g., education has a different effect on health in each/some of the 21 countries). However, this is not our focus in this study.

${ }^{5}$ A series of empirical papers demonstrates the "Healthy Immigrant Effect" - Immigrants tend to be healthier than natives, shortly after arrival in the host countries. However, immigrants' health deteriorates with time, and decreases to levels that are equal, or even below, the health level of natives (see, for instance Jasso et al., 2004; Constant et al., 2018). As we are pooling all immigrants (with different duration times in the host countries), and as the share of new arrivals is relatively low in our sample - the overall effect of an immigrant status is negative.
} 
less chronic diseases. Highly educated individuals, most probably, have the knowledge how to better control diseases, and therefore are healthier; widowed individuals report more chronic diseases compared to those who belong to any other group (single, divorced); members of households with financial difficulties feel less healthy and suffer from more chronic diseases. ${ }^{6}$ We also experimented with alternative wealth measures of the household, like - the income centile that the household belongs to, and pensions received by the household. The results were similar: a positive relationship between household wealth and health; employed individuals report better health compared to unemployed individuals and, unemployed individuals suffer from less chronic diseases compared to individuals who belong to all other occupational categories (excepted the category of employed); interestingly, living parents add significantly to the subjective valuation of health and also to the objective health measure (diseases). An explanation for this finding can be related to genetics - parents of individuals who are at the age of 50 and over, must be at least in their 70s. This is an indication of high life expectancy that might affect the health status of their offspring; Obese individuals report worse health in the two health dimensions; People with better memory report better health. ${ }^{7}$

The results for the socio-economic background variables are similar for natives and immigrants.

Of special interest are the coefficients of the country dummies, which measure the aggregate, average contribution of the country of residence to the health of its residents, beyond the effects of all other personal explanatory variables that are included in the regression analyses. These coefficients reflect country differences in health (versus Austria, the reference country).

In the next subsection we test whether these country coefficients (for the whole sample, and for the natives' and immigrants' sub-samples) are correlated with country-specific macro development measures.

\subsection{Correlations between health country effects and country-specific macro development} measurements

\footnotetext{
${ }^{6}$ Causality could run in the opposite direction: a disadvantaged health status, could lead to financial difficulties.

${ }^{7}$ Good memory is an indicator of cognitive skills. Experimenting with other proxies for cognitive skills (for instance, the number of animals that the respondent lists in one minute) led to similar results: a positive relationship between cognitive skills and health.
} 
While the effects of the various personal health determinants (revealed by regression analyses) are interesting, a more novel question that this paper attempts to address is whether objective country-specific development measurements are significantly correlated with the country coefficients (that represent deviations from the coefficient of the reference country of Austria).

The country-specific objective economic performance indicators, which are employed in our study, are:

- Logarithm of per-capita GDP (average value for the years 2004-2017, that correspond to the SHARE waves used for regression analyses; Source: OECD, 2019). Per-capita GDP is the most common indicator for a country's level of economic development and economic performance. It is also used as a marker of the population's standard of living. The logarithm of GDP per-capita (that relates to the annual change in GDP per-capita) is often used in empirical studies as the preferred measure of development and economic performance (Sacks et al., 2010; Clark and Senik, 2011; Easterlin et al., 2010);

- Human Development Index (HDI, average value for the years 2004-2017; Source: United Nations, 2019). The Human Development Index, which is published by the United Nations Development Program, is a composite summary measure of human development. It combines indicators of health, education and standard-ofliving. The HDI ranges from 0 to 1 , and a higher value indicates a more developed country. It provides an alternative to the common practice of evaluating a country's development level based on per-capita GDP;

- Social Progress Index (SPI, average value for 2014-2017 - which are the only four relevant years for which we have SPI country-level data; Source: Social Progress Index, 2019). The Social Progress Index is based on 54 indicators of social and environmental outcomes that belong to three dimensions: Basic human needs, foundations of well-being, and opportunities. The index is published by the non-profit Social Progress Imperative. A higher value indicates a more socially advanced country. The use of this measure of development is in line with the recent literature that claims and shows that social and environmental aspects are 
major determinants of the residents' well-being and their quality of life, thus also affecting their health (e.g., Helliwell et al., 2010). ${ }^{8}$

We include two additional country development characteristics, more specifically linked to health:

- Life expectancy at birth (average value for years 2004-2017; Source: OECD, 2019). Life expectancy at birth is defined as the average number of years that a newborn is expected to live, assuming that current mortality rates will not change;

- Percentage of GDP spent on health (average value for the years 2004-2017; Source: OECD-Health, 2019). Includes consumption of health-care goods and services, proxied by government spending on health, as well as voluntary health insurance payments.

The last macro included in the correlation analysis, measures the countries' environmental health:

- Environmental Health Index (average value for the years 2008-2016, for which we have country-level data; Source: Wendling et al, 2018). The Environmental Health Index relates to three categories of environmental concern: air quality, water and sanitation quality, and prevalence of toxic heavy metals (in water, soil, food). Higher scores indicate less environmental damage, and thus better environmental health. ${ }^{9}$

The country-specific measures of these six macros are presented in Appendix Table A.2.

Spearman rank correlations between country coefficients and the macro measurements listed above, were calculated and tested for significance. We preferred the Spearman rank correlation coefficient, because it does not impose a linear relationship and has reduced sensitivity to extreme values, compared to the Pearson correlation coefficient. Calculations

\footnotetext{
${ }^{8}$ There is no data on the SPI of Luxembourg and Malta. These two countries were therefore excluded from the correlation analysis of SPI versus health.

${ }^{9}$ Wendling et al. (2018) also relate to another environmental measure, namely: "ecosystem vitality". They then suggest an environmental index that combines the two indices of "environmental health" and "ecosystem vitality": EPI - Environmental Performance Index. We use only the component of "environmental health", because it is more closely related to economic performance and growth (Trasande, 2019).
} 
and significance tests for the Spearman coefficients are repeated for the three samples of the two models (whole sample, natives, and immigrants) and presented in Tables 5 and 6. Results using the Pearson correlation coefficients are presented in Appendix Tables A.3 and A.4.

Table 5: Spearman correlations between country development measures and SAHS country coefficients

\begin{tabular}{lccc}
\hline Correlation between country & $\begin{array}{c}\text { Whole } \\
\text { sample }\end{array}$ & Natives & Immigrants \\
\hline \hline Logarithm of per-capita GDP & $0.614^{* * *}$ & $0.603^{* * *}$ & $0.524^{* * *}$ \\
& $(0.000)$ & $(0.001)$ & $(0.004)$ \\
HDI- Human Development Index & $0.566^{* * *}$ & $0.560^{* * *}$ & $0.427 * *$ \\
& $(0.001)$ & $(0.002)$ & $(0.021)$ \\
SPI - Social Progress Index & $0.466^{* *}$ & $0.450^{* *}$ & $0.441 * *$ \\
& $(0.014)$ & $(0.019)$ & $(0.021)$ \\
Life expectancy at birth & $0.575^{* * *}$ & $0.578^{* * *}$ & $0.729 * * *$ \\
& $(0.001)$ & $(0.001)$ & $(0.000)$ \\
Percentage of GDP spent on & $0.493^{* * *}$ & $0.477 * * *$ & $0.630^{* * *}$ \\
health & $(0.007)$ & $(0.009)$ & $(0.000)$ \\
Environmental Health Index & $0.570^{* * *}$ & $0.571 * * *$ & $0.495^{* * *}$ \\
& $(0.001)$ & $(0.001)$ & $(0.006)$ \\
\hline \hline
\end{tabular}

Table 6: Spearman correlations between country development measures and country coefficients of 'number of chronic diseases'

\begin{tabular}{lccc}
\hline $\begin{array}{l}\text { Correlation between country } \\
\text { dummies and: }\end{array}$ & $\begin{array}{c}\text { Whole } \\
\text { sample }\end{array}$ & Natives & Immigrants \\
\hline \hline Logarithm of per-capita GDP & 0.102 & 0.134 & 0.064 \\
& $(0.592)$ & $(0.490)$ & $(0.741)$ \\
HDI- Human Development & 0.094 & 0.120 & 0.170 \\
Index & $(0.626)$ & $(0.536)$ & $(0.379)$ \\
SPI - Social Progress Index & 0.081 & 0.112 & 0.098 \\
& $(0.690)$ & $(0.577)$ & $(0.626)$ \\
Life expectancy at birth & -0.054 & -0.028 & -0.221 \\
& $(0.780)$ & $(0.885)$ & $(0.249)$ \\
Percentage of GDP spent on & -0.137 & -0.083 & -0.265 \\
health & $(0.476)$ & $(0.670)$ & $(0.165)$ \\
Environmental Health Index & 0.191 & 0.210 & 0.097 \\
& $(0.322)$ & $(0.273)$ & $(0.618)$ \\
\hline \hline
\end{tabular}

Notes: $\mathrm{p}$-values in parentheses; $*$ significant at $0.10 ; * *$ significant at $0.05 ; * * *$ significant at 0.01 
The results presented in Tables 6 and 7 demonstrate clearly and consistently, that correlations between country health dummies and country development levels, show a very different pattern when health measures are subjective or objective. When subjective measures (SAHS) are considered - the country levels of SAHS are positively and significantly correlated with all the country development measurements, and this is the case for the whole sample and also for the natives' and immigrants' sub-samples. None of the correlations of development with country-level chronic diseases s significant.

While Table 5 does not indicate any systematic differences between natives and the sample of all immigrants pooled together, it could still be the case that recent immigrants are different from immigrants who stayed longer in the receiving country. To examine if the SAHS-Development associations vary by years-since-migration (ysm), we have divided the sample of immigrants into three sub-samples (using cut-off points of percentiles 33 and 66): immigrants with less than 33 years-since-migration ( ysm between 33 and 51 years (sample size $=1176$ ) and immigrants with more than 51 years since migration (sample size $=1112$ ). Spearman correlation coefficients (between SAHS and development measures) and their significance levels are presented in Table 7 (the regression models for these samples are available upon request).

Table 7: Spearman correlations between country development levels and SAHS country coefficients, for immigrant sub-samples

\begin{tabular}{lccc}
\hline $\begin{array}{l}\text { Correlation between country } \\
\text { dummies and: }\end{array}$ & ysm $<33$ & $33 \leq \mathrm{ysm} \leq 51$ & $\mathrm{ysm}>51$ \\
\hline \hline Logarithm of per-capita GDP & 0.199 & 0.252 & $0.724^{* * * *}$ \\
& $(0.309)$ & $(0.196)$ & $(0.000)$ \\
HDI- Human Development Index & 0.071 & 0.230 & $0.657^{* * *}$ \\
& $(0.719)$ & $(0.239)$ & $(0.000)$ \\
SPI - Social Progress Index & 0.095 & 0.228 & $0.625^{* * *}$ \\
& $(0.640)$ & $(0.263)$ & $(0.001)$ \\
Life expectancy at birth & 0.310 & $0.684^{* * *}$ & $0.745^{* * *}$ \\
& $(0.109)$ & $(0.000)$ & $(0.000)$ \\
Percentage of GDP spent on & 0.309 & $0.357^{*}$ & $0.731^{* * *}$ \\
health & $(0.109)$ & $(0.063)$ & $(0.000)$ \\
Environmental Health Index & 0.145 & 0.308 & $0.573^{* * *}$ \\
& $(0.453)$ & $(0.111)$ & $(0.002)$ \\
\hline \hline
\end{tabular}

Notes: p-values in parentheses; * significant at $0.10 ; * *$ significant at $0.05 ; * * *$ significant at 0.01. The Romanian sample does not include immigrants with less than $51 \mathrm{ysm}$ 
As is demonstrated in Table 7, correlations coefficients are only significant for the subsamples of more 'veteran' immigrants. None of the Spearman correlations is significant for the more recent immigrants who reside in the receiving country for three decades or less.

A summary of the results, focusing on the two health measures, and on the native-immigrant comparison follows:

(i) When the SAHS subjective-health measure is used (SAHS model), the country levels of self-assessed-health are positively and significantly correlated with the country development measurements, i.e., individuals in countries with higher development levels, report better subjective-health. This is the case for the whole sample and for the natives' and immigrants' sub-samples.

Scatter plots of the relationships between subjective-health and development, for the whole sample, are presented in Figure 1, and further clearly demonstrate the pronounced positive correlation between health and development of the 29 countries in our sample.

Interestingly, the most pronounced correlation coefficient (together with 'life expectancy at birth') relates to the Environmental Health Index (0.570). A growing recent literature documents the effects of environmental hazards on both the economy, and on health (in particular child health and disease). See for instance, Landrigan et al. (2005), Trasande et al. (2005), Hauser et al., (2015) and Trasande et al., (2015). These parallel effects on health and on economic performance - result in the observed elevated correlation between the two. 
Figure 1: Scatter diagrams and Pearson correlations, between country development measures (horizontal axis) and country SAHS effects (vertical axis), for the whole sample

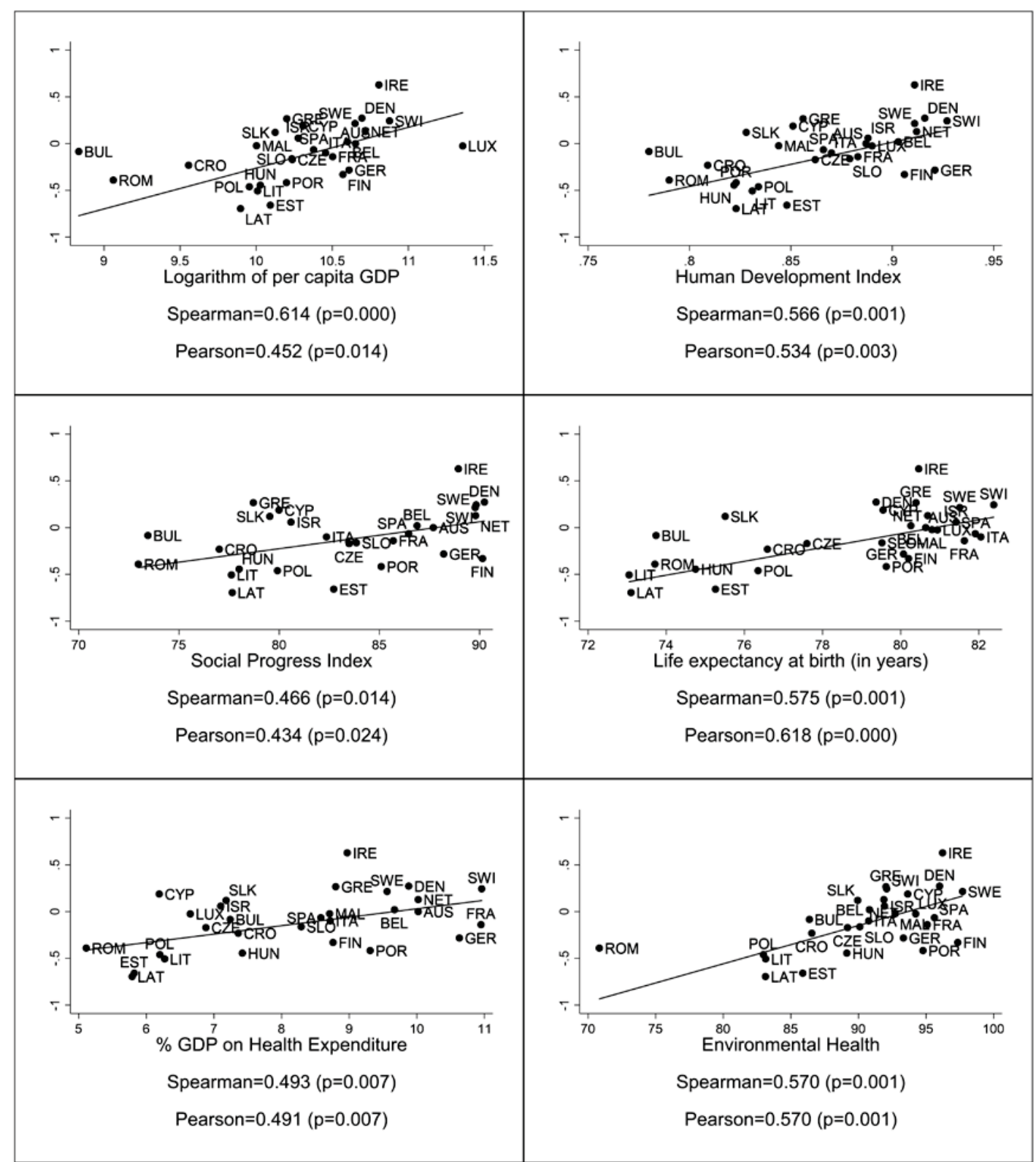

Notes: Vertical axis= fixed-effects country coefficients, based on SAHS regression (Table 3); Horizontal axis $=$ country macro measures

(ii) In sharp contrast with the positive significant correlation coefficients between 
subjective-health and development - we do not find significant correlations between development and the more objective health measure - 'number of chronic diseases' (Table 6). This is the case for the whole sample and also for the sub-samples (natives and immigrants). We are conscious that, given the small sample size (29 countries), only large correlation indices could possibly be significant. But it is still clear that the association of macro-variables with the objective health measure is much less pronounced (if existent at all), compared to the association with the subjective measure. A potential explanation for this clear-cut finding is that the effect of the country's level of development on health is psychological rather than actual. Individuals who live in more developed countries feel healthier (in their 'internal' view of health). Maybe, because they benefit from better health-care services, or because they expect better treatment in case they will need medical treatment and cure. ${ }^{10}$ The more objective 'external' view of health, proxied by 'number of chronic diseases', does not seem to be correlated with the country's development level. It follows, that in studies that focus on context/country effects on health, the selection of health measures is crucial. Different health measures could lead to different results.

(iii) Results presented in Table 7 show that the relationship between the country's development level and the individuals' subjective-health vary also by immigration status (years-since-migration): All the associations are insignificant for more recent immigrants (33 years or less) and correlation coefficients are significant for immigrants with more than three decades in their host country.

\section{Concluding remarks and discussion}

\footnotetext{
${ }^{10}$ Interestingly, the explanation of psychological effects behind self-rated health gets some support from a recent paper published in the New England Journal of Medicine (Baicker et al., 2013), based on data from a natural experiment in the US State of Oregon. The 2008 Medicaid expansion in Oregon was based on lottery drawings, which granted low-income adults in Oregon free Medicaid. Approximately two years after the lottery, data were obtained from 6387 adults who were randomly selected to receive free Medicaid coverage, and 5842 adults who were not selected. Measures included self-rated health status, screening for depression, health-care utilization, and measures of blood pressure, cholesterol, and glycated hemoglobin levels. The randomized, controlled study showed that Medicaid coverage generated no significant improvements in measured physical health outcomes in the first two years (parallel to our results of insignificant correlations between development and chronic diseases). However, it did increase self-ratings of health, lower rates of depression, and reduce financial strain (in line with our positive significant correlations between development and self-assessed-health-status).
} 
Our empirical study, based on data for more than 105,000 respondents (aged 50 and over), from 29 European countries, leads to the following core findings/conclusions:

(i) Country-specific economic development variables (six measures) and aggregate country-level subjective-health (netted out of personal sociodemographic characteristics) are positively and significantly correlated. A novel development measure, introduced in this study, is the Environmental Health Index (that relates to three categories of environmental hazards: air quality, water and sanitation quality, and prevalence of toxic heavy metals). Interestingly, this measure exhibits the most pronounced correlations with subjective-health.

It therefore appears that it is not only 'who you are' that affects the individual's subjective perception of health, but also 'in which country you live': residents in more developed European countries report better subjectivehealth. Parallel positive correlations have been found for development measures vis-a-vis subjective-well-being/happiness (Deaton, 2008).

(ii) Our finding of the significant association between development and perceived-health contributes to the growing literature that focuses on the effects of contextual variables on various dimensions of the individual's life and behavior. The epidemiological literature emphasizes the effects of the environment/place of residence on health [e.g., Diez-Roux, 2001; Pickett and Pearl, 2001; Landrigan et al., 2005].

(iii) The findings of positive significant correlations between the countries' development level and the subjective-health of residents, has policy implications: improvement of development measures affects perceived-health above and beyond the more documented effect on well-being. Better subjective-health could consequently lead to a more efficient use of welfare and public-health budgets (e.g., if less is demanded for health-care, funds can be redirected to para-medical uses, such as, preventive health or the improvement of patients' quality of life);

(iv) In sharp contrast with the significant correlations between perceived/subjective-health and country-level development, we do not find any 
significant correlation between development and the more objective health measure ('number of chronic diseases that the respondent was diagnosed with'). These findings ((iii) and (iv)) support Hypothesis 1 that expects: more pronounced correlations between development measures and the subjectivehealth measure, compared to correlations between development and an objective health measure. This Hypothesis is based on the speculation that psychological elements are at work. Naturally, psychological dimensions are more closely related to perceived-health (and similarly to subjective-wellbeing), than to the more objective health records;

(v) It follows that we need to be careful and avoid jumping into universal conclusions claiming that contextual/development factors affect health. They might affect only specific dimensions of health (probably subjective/perceived-health);

(vi) In order to further investigate the option that the driving forces behind the development-health association are mainly psychological, we split the sample into two sub-samples of natives and immigrants. If, indeed, the correlation is driven by psychological elements - we would expect weaker, and maybe insignificant, correlations within the immigrant sub-sample. The results do not demonstrate this- the development-health correlations are significant for all 6 development measures within both the natives' and the immigrants' subsamples. These findings do not lend support to Hypothesis 2: healthdevelopment correlations will be more pronounced and significant within the sample of natives, than within the immigrants' sample;

(vii) In the same vein, when we further distinguish (within the immigrants' sample), between more recent immigrants (three decades or less in the receiving country), and immigrants with a longer duration - it is found that all correlation coefficients are insignificant for the former. It therefore appears that after three decades immigrants assimilate and their psychological attitudes converge towards those of native residents - they too are now affected psychologically by the development merits of the country. 
(viii) The results reported in this paper relate to older populations (50 and over) and to European countries (most of them are developed). Replications of this study for more general populations, and for a wider range of country development levels, could be useful and could lead to the generalization of our results.

\section{References}

Acemoglu, D., Johnson, S.: Disease and Development: The Effect of Life Expectancy on Economic Growth. Journal of Political Economy: 115(6), 925-985 (2007)

Baicker, K., Taubman, S.L., Allen, H.L., Bernstein, M., Gruber, J.H., Newhouse, J.P., Schneider, E.C., Wright, B.J., Zaslavsky, A.M., Finkelstein A.M. et al.: The Oregon Experiment - Effects of Medicaid on Clinical Outcomes. The New England Journal of Medicine: 368, 1713-1722 (2013)

Bago d'Uva, T., van Doorlsaer, E., Lindeboom, M., O'Donnell, O.: Does Reporting Heterogeneity Bias the Measurement of Health Disparities? Health Economics: 17(3), 351-375 (2008)

Bloom, D.E., Canning, D., Sevilla, J.: The Effect of Health on Economic Growth: A Production Function Approach. World Development: 32(1), 1-13 (2004)

Börsch-Supan, A.: Survey of Health, Ageing and Retirement in Europe Wave 1. Release version: 6.1.0. SHARE-ERIC. Data set (2018a). DOI:10.6103/SHARE.w1.610

Börsch-Supan, A.: Survey of Health, Ageing and Retirement in Europe Wave 2. Release version: 6.1.0. SHARE-ERIC. Data set (2018b). DOI:10.6103/SHARE.w2.610

Börsch-Supan, A.: Survey of Health, Ageing and Retirement in Europe Wave 4. Release version: 6.1.0. SHARE-ERIC. Data set (2018c). DOI:10.6103/SHARE.w4.610

Börsch-Supan, A.: Survey of Health, Ageing and Retirement in Europe Wave 5. Release version: 6.1.0. SHARE-ERIC. Data set (2018d). DOI:10.6103/SHARE.w5.610

Börsch-Supan, A.: Survey of Health, Ageing and Retirement in Europe Wave 6. Release version: 6.1.0. SHARE-ERIC. Data set (2018e). DOI:10.6103/SHARE.w6.610

Börsch-Supan, A.: Survey of Health, Ageing and Retirement in Europe Wave 7. Release version: 7.0.0. SHARE-ERIC. Data set (2019). DOI: 10.6103/SHARE.w7.700

Clark, A.E., Senik, C.: Will GDP Growth Increase Happiness in Developing Countries? In: Peccoud R. (ed.), Measure for Measure: How Well Do we Measure Development? Paris: STIN, 99-176 (2011)

Constant, A., García-Muñoz, T., Neuman, S., Neuman, T.: A 'Healthy Immigrant 
Effect' or a 'Sick Immigrant Effect'? - Selection and Policies Matter. European Journal of Health Economics: 19, 103-121 (2018)

Deaton, A.: Height, Health and Development. Proceedings of the National Academy of Sciences, USA: 104(33), 13232-13237 (2007)

Deaton, A.: Income, Health and Well-Being around the World: Evidence from the Gallup World Poll. Journal of Economic Perspectives: 22(2), 53-72 (2008)

Diez-Roux A.V.: Investigating Neighborhood and Area Effects on Health. American Journal of Public Health: 91(11), 783-789 (2001)

Easterlin, R.A., McVey, L.A., Switek, M., Sawangfa, O., Zweig, J.S.: The HappinessIncome Paradox Revisited. Proceedings of the National Academy of Sciences, USA: 107(52), 22463-22468 (2010)

Helliwell, J.F., Barrington-Leigh, C., Harris, A., Huang, H.: International Evidence on the Social Context of Wellbeing. In: Diener, E., Helliwell, J.F., Kahneman, D. (eds), International Differences in Wellbeing. Oxford University Press (2010)

Hauser, R., Skakkebaek, N.E., Hass, U., Toppari, J., Juul, A, Anderson, A.M.: Male Reproductive Disorders, Diseases, and Costs of Exposure to Endocrine-disrupting Chemicals in the European Union. The Journal of Clinical Endocrinology \& Metabolism: 100(4), 1267-1277 (2015)

Jasso, G., Massey, D.S., Rosenzweig, M.R., Smith, J.: Immigrant Health: Selectivity and Acculturation. In: Anderson, N.B., Bulatao, R.A., Cohen, B. (eds.) Critical Perspectives on Racial and Ethnic Differences in Health in Late Life (pp. 227-266). National Academic Press, Washington, DC (2004)

Jürges, H.: True Health versus Response Style: Exploring Cross-Country Differences in Self-Reported Health. Health Economics Review: 16(2), 163-178 (2007)

Kleinman, A.: The Illness Narrative: Suffering, Healing and the Human Condition. New-York: Basic Books (1988)

Kleinman, A.: Writing at the Margin: Discourse between Anthropology and Medicine. Berkeley: University of California Press (1995)

Landrigan, P.J., Sonawane, B., Butler, L., Trasande, L., Callan, R., Droller, D.: Early Environmental Origins of Neurodegenerative Disease in Later Life. Environmental Health Perspectives: 113(9): 1230 (2005)

Mora, P.A., Di'Bonaventura, M.D., Idler, E., Leventhal, E., Leventhal, H.: Psychological Factors Influencing Self-Assessments of Health: Toward an Understanding of the Mechanisms Underlying How People Rate Their Own Health. Annals of Behavioral Medicine: 36, 292-303 (2008) 
Neuman S.: Are Immigrants Healthier than Native Residents? IZA World of Labor Series No. 108 (2014)

OECD-Health: Health Spending (indicator). doi: 10.1787/8643de7e-en. Accessed on May $12^{\text {th }}, 2019$

OECD stats: http://stats.oecd.org. Accessed on May $9^{\text {th }} 2019$

Olsen, K.M., Dahl, S.A.: Health Differences between European Countries. Social Science and Medicine: 64, 1665-1678 (2007)

Oswald, A.J., Wu, S.: Objective Confirmation of Subjective Measures of Human WellBeing: Evidence from the USA. Science: 327, 576-579 (2010)

Pickett K.E., Pearl M.: Multilevel Analyses of Neighborhood Socioeconomic Context and Health Outcomes: A Critical Review. Journal of Epidemiology and Community Health: 55, 1111-22 (2001)

Ploubidis, G.B., Dale, C., Grundy, E.: Later life Health in Europe: How Important are Country Level Influences? European Journal of Ageing: 9, 5-13 (2012)

Ruhm, C: Are Recessions Good for your Health? Quarterly Journal of Economics: 115, 617-650 (2000)

Ruhm, C.: Macroeconomic Conditions, Health and Mortality. In: Jones, A. (ed.) Elgar Companion to Health Economics. Cheltenham, UK: Edward Elgar Publishing (2006)

Ruhm, C.: A Healthy Economy Can Break your Heart. Demography: 44, 829-48 (2008)

Sacks, D.W., Stevenson, B., Wolfers, J.: Subjective Well-Being, Income, Economic Development and Growth. Discussion Paper No. 5230. IZA: Bonn (2010)

Salomon, J., Tandon, A., Murray, C.: Comparability of Self-Rated Health: Cross Sectional Multi-Country Survey using Anchoring Vignettes. British Medical Journal: 328, 258-261 (2004)

Sen, A.: Health: Perception versus Observation. British Medical Journal: 324(13), 860$861(2002)$

Smith, J.P.: Healthy Bodies and Thick Wallets: The Dual Relation Between Health and Economic Status. Journal of Economic Perspectives: 13(2), 145-166 (1999)

Social Progress Index. http://www.socialprogressindex.com. Accessed on May $9^{\text {th }}$, 2019

Subramanian S.V., Belli, P., Kawachi I.: The Macroeconomic Determinants of Health. Annual Review of Public Health: 23, 287-302 (2002) 
Trasande, L.: Sicker, Fatter, Poorer. New York: Houghton, Mifflin and Harcourt Publishing Company (2019)

Trasande, L., Landrigan, P.J., Schechter, C.: Public Health and Economic Consequences of Methyl Mercury. Environmental Health Perspectives 113(5), 590 (2005)

Trasande, L., Zoeller, R.T., Hass, U., Kortenkamp, A., Grandjean, P., Myers, J.P.: Estimating Burden and Disease Costs of Exposure to Endocrine -disrupting Chemicals in the European Union. The Journal of Clinical Endocrinology \& Metabolism 100(4), 1245$1255(2015)$

United Nations: http://hdr.undp.org/en/statistics/hdi/. Accessed on May 9 ${ }^{\text {th }}, 2019$

Wendling, Z.A., Emerson, J.W., Esty, D.C., Levy, M.A., de Sherbinin, A., et al.: Environmental Performance Index. New Haven, CT: Yale Center for Environmental Law \& Policy. https://epi.yale.edu/ (2018)

WHO: Commission on Macroeconomics and Health: Macroeconomics and Health: Investing in Health for Economic Development. Geneva: World Health Organization (2001) 


\section{APPENDIX}

Table A.1: Sample characteristics

Mean (standard deviation)

Whole Sample Natives Immigrants

\begin{tabular}{rrrrr}
\hline \hline Dependent variables & & & \\
& SAHS (range of 1-5) & $2.77(1.06)$ & $2.79(1.06)$ & $2.66(1.09)$ \\
Number of chronic diseases & $1.22(1.25)$ & $1.22(1.25)$ & $1.28(1.34)$
\end{tabular}

(i) Socio-demographic personal variables

$\begin{array}{llll}\text { Female (\%) } & 54.76 & 54.78 & 54.24\end{array}$

Age in years $(\%)$

$\begin{array}{rrrr}50-60 & 25.41 & 24.99 & 38.20 \\ 61-70 & 35.39 & 35.58 & 29.67 \\ 71-80 & 25.78 & 25.91 & 21.63 \\ \text { Over } 80 & 13.42 & 13.52 & 10.50\end{array}$

Education (respondent completed the first

and/or second stage of tertiary educ.) (\%)

20.57

20.38

26.32

Marital status (\%)

$\begin{array}{rlll}\text { Divorced, separated, single } & 15.68 & 15.66 & 16.29 \\ \text { Married } & 68.79 & 68.77 & 69.41 \\ \text { Widowed } & 15.53 & 15.57 & 14.30\end{array}$

Parents alive (\%)

$\begin{array}{rccc}\text { Mother } & 19.52 & 19.38 & 23.94 \\ \text { Father } & 7.91 & 7.85 & 9.88 \\ \text { Difficulties to make financial ends meet (\%) } & 11.68 & 11.46 & 18.28\end{array}$

Current occupational status (\%)

\begin{tabular}{rrccc} 
& Unemployed & 2.45 & 2.35 & 6.05 \\
& Retired & 60.23 & 60.61 & 48.58 \\
& Employed & 24.13 & 23.96 & 29.29 \\
& Homemaker & 8.44 & 8.42 & 9.02 \\
& Sick & 3.19 & 3.11 & 5.46 \\
& Other & 1.56 & 1.55 & 1.60 \\
\hline \hline (ii) Behavioral risk (\%) & & & & \\
& Obese (BMI>30) & 22.03 & 22.00 & 22.94 \\
\hline \hline
\end{tabular}




\begin{tabular}{|c|c|c|c|}
\hline \multicolumn{4}{|l|}{ (iii) Memory/cognitive skills } \\
\hline Recall words (range of 0-10) & $5.08(1.87)$ & $5.09(1.87)$ & $4.67(1.97)$ \\
\hline \multicolumn{4}{|l|}{ (iv) Wave shares in the sample } \\
\hline Wave 1 & 5.30 & 4.61 & 25.92 \\
\hline Wave 2 & 5.36 & 5.28 & 7.74 \\
\hline Wave 4 & 5.70 & 5.60 & 8.87 \\
\hline Wave 5 & 11.77 & 11.42 & 22.55 \\
\hline Wave 6 & 11.58 & 11.61 & 10.80 \\
\hline Wave 7 & 60.29 & 61.48 & 24.12 \\
\hline \multicolumn{4}{|l|}{ (v) Country shares in the sample (\%) } \\
\hline Austria & 4.71 & 4.75 & 3.15 \\
\hline Germany & 6.47 & 6.25 & 13.38 \\
\hline Sweden & 5.05 & 5.10 & 3.68 \\
\hline The Netherlands & 4.93 & 4.91 & 5.55 \\
\hline Spain & 5.88 & 6.02 & 1.90 \\
\hline Italy & 6.60 & 6.79 & 0.71 \\
\hline France & 5.91 & 5.90 & 6.08 \\
\hline Denmark & 4.51 & 4.62 & 1.18 \\
\hline Greece & 4.89 & 4.98 & 2.31 \\
\hline Switzerland & 3.00 & 3.00 & 3.03 \\
\hline Belgium & 6.84 & 6.84 & 6.80 \\
\hline Israel & 1.67 & 1.26 & 14.12 \\
\hline The Czech Republic & 6.44 & 6.56 & 2.82 \\
\hline Poland & 5.12 & 5.21 & 2.23 \\
\hline Ireland & 0.30 & 0.28 & 0.59 \\
\hline Luxembourg & 1.34 & 1.16 & 6.82 \\
\hline Hungary & 1.74 & 1.79 & 0.27 \\
\hline Portugal & 1.57 & 1.60 & 0.59 \\
\hline Slovenia & 3.88 & 3.91 & 2.85 \\
\hline Estonia & 4.51 & 4.57 & 2.82 \\
\hline Croatia & 2.21 & 2.12 & 4.72 \\
\hline Lithuania & 1.82 & 1.77 & 3.35 \\
\hline Bulgaria & 1.77 & 1.81 & 0.33 \\
\hline
\end{tabular}




\begin{tabular}{rccc} 
Cyprus & 0.96 & 0.97 & 0.65 \\
Finland & 1.73 & 1.78 & 0.33 \\
Latvia & 1.46 & 1.22 & 9.02 \\
Malta & 0.99 & 1.02 & 0.15 \\
Romania & 1.85 & 1.92 & 0.12 \\
Slovakia & 1.85 & 1.89 & 0.45 \\
\hline Samples Size & 105,857 & 102,487 & 3,370 \\
\hline
\end{tabular}

Table A.2: Country-level development variables

\begin{tabular}{|c|c|c|c|c|c|c|}
\hline Country & $\begin{array}{l}\text { Log of per- } \\
\text { capita GDP }\end{array}$ & $\begin{array}{l}\text { Human } \\
\text { Development } \\
\text { Index }\end{array}$ & $\begin{array}{l}\text { Social } \\
\text { Progress } \\
\text { Index }\end{array}$ & $\begin{array}{c}\text { Life } \\
\text { expectancy } \\
\text { at birth } \\
\text { (years) }\end{array}$ & $\begin{array}{c}\text { Percentage } \\
\text { of GDP } \\
\text { spent on } \\
\text { health }\end{array}$ & $\begin{array}{l}\text { Environmental } \\
\text { Health Index }\end{array}$ \\
\hline Austria & 10.65 & 0.887 & 87.69 & 80.64 & 10.02 & 93.03 \\
\hline Germany & 10.61 & 0.921 & 88.21 & 80.07 & 10.63 & 93.32 \\
\hline Sweden & 10.65 & 0.911 & 89.78 & 81.51 & 9.56 & 97.70 \\
\hline The Netherlands & 10.72 & 0.912 & 89.80 & 80.69 & 10.02 & 91.87 \\
\hline Spain & 10.38 & 0.866 & 86.46 & 81.91 & 8.58 & 95.61 \\
\hline Italy & 10.45 & 0.870 & 82.36 & 82.05 & 8.72 & 90.76 \\
\hline France & 10.50 & 0.883 & 85.69 & 81.63 & 10.95 & 95.09 \\
\hline Denmark & 10.69 & 0.916 & 90.24 & 79.37 & 9.88 & 96.00 \\
\hline Greece & 10.20 & 0.856 & 78.71 & 80.39 & 8.80 & 92.03 \\
\hline Switzerland & 10.88 & 0.927 & 89.83 & 82.38 & 10.96 & 92.08 \\
\hline Belgium & 10.60 & 0.903 & 86.88 & 80.26 & 9.67 & 90.81 \\
\hline Israel & 10.28 & 0.888 & 80.59 & 81.42 & 7.10 & 91.92 \\
\hline The Czech Republic & 10.24 & 0.862 & 83.49 & 77.60 & 6.88 & 89.19 \\
\hline Poland & 9.96 & 0.834 & 79.91 & 76.35 & 6.20 & 82.97 \\
\hline Ireland & 10.81 & 0.911 & 88.94 & 80.46 & 8.97 & 96.22 \\
\hline Luxembourg & 11.36 & 0.890 & - & 80.94 & 6.65 & 94.23 \\
\hline Hungary & 10.07 & 0.822 & 78.00 & 74.75 & 7.42 & 89.13 \\
\hline Portugal & 10.20 & 0.823 & 85.09 & 79.63 & 9.31 & 94.77 \\
\hline Slovenia & 10.23 & 0.879 & 83.85 & 79.52 & 8.29 & 90.10 \\
\hline Estonia & 10.09 & 0.848 & 82.72 & 75.26 & 5.82 & 85.87 \\
\hline Croatia & 9.56 & 0.809 & 77.01 & 76.59 & 7.36 & 86.54 \\
\hline Lithuania & 10.01 & 0.831 & 77.62 & 73.05 & 6.27 & 83.14 \\
\hline Bulgaria & 8.83 & 0.780 & 73.45 & 73.74 & 7.24 & 86.37 \\
\hline Cyprus & 10.31 & 0.851 & 79.99 & 79.55 & 6.19 & 93.64 \\
\hline Finland & 10.57 & 0.906 & 90.15 & 80.20 & 8.76 & 97.34 \\
\hline Latvia & 9.90 & 0.823 & 77.66 & 73.10 & 5.79 & 83.12 \\
\hline Malta & 10.00 & 0.844 & - & 80.80 & 8.71 & 92.71 \\
\hline Romania & 9.06 & 0.790 & 72.97 & 73.71 & 5.11 & 70.83 \\
\hline Slovakia & 10.12 & 0.828 & 79.53 & 75.51 & 7.18 & 89.94 \\
\hline
\end{tabular}

Data sources: OECD and OECD-Health (2019); United Nations (2019); Social Progress Index (2018) 
Table A.3: Pearson correlations between country development measures and SAHS country coefficients

\begin{tabular}{lccc}
\hline \hline $\begin{array}{l}\text { Correlation between country } \\
\text { dummies and: }\end{array}$ & $\begin{array}{c}\text { Whole } \\
\text { sample }\end{array}$ & Natives & Immigrants \\
\hline Logarithm of per-capita GDP & $0.452^{* *}$ & $0.444^{* *}$ & $0.410^{* *}$ \\
& $(0.014)$ & $(0.016)$ & $(0.027)$ \\
HDI- Human Development Index & $0.534^{* * *}$ & $0.530^{* * *}$ & $0.416^{* *}$ \\
& $(0.003)$ & $(0.003)$ & $(0.025)$ \\
SPI - Social Progress Index & $0.434^{* *}$ & $0.417^{* *}$ & $0.446^{* *}$ \\
& $(0.024)$ & $(0.031)$ & $(0.020)$ \\
Life expectancy at birth & $0.618^{* * *}$ & $0.616^{* * *}$ & $0.708^{* * *}$ \\
& $(0.000)$ & $(0.004)$ & $(0.000)$ \\
Percentage of GDP spent on & $0.491^{* * *}$ & $0.466^{* *}$ & $0.649^{* * *}$ \\
health & $(0.007)$ & $(0.010)$ & $(0.000)$ \\
Environmental Health Index & $0.570^{* * *}$ & $0.563^{* * *}$ & $0.582^{* * *}$ \\
& $(0.001)$ & $(0.002)$ & $(0.001)$ \\
\hline \hline
\end{tabular}

Notes: p-values in parentheses; $* *$ significant at $0.05 ; * * *$ significant at 0.01

Table A.4: Pearson correlations between country development measures and country coefficients of 'number of chronic diseases'

\begin{tabular}{lccc}
\hline \hline $\begin{array}{l}\text { Correlation between country } \\
\text { dummies and: }\end{array}$ & $\begin{array}{c}\text { Whole } \\
\text { sample }\end{array}$ & Natives & Immigrants \\
\hline \hline Logarithm of per-capita GDP & 0.289 & $0.329 *$ & 0.262 \\
& $(0.123)$ & $(0.081)$ & $(0.169)$ \\
HDI- Human Development & 0.220 & 0.250 & 0.276 \\
Index & $(0.253)$ & $(0.191)$ & $(0.147)$ \\
SPI - Social Progress Index & 0.192 & 0.241 & 0.202 \\
& $(0.339)$ & $(0.227)$ & $(0.311)$ \\
Life expectancy at birth & 0.245 & 0.282 & 0.018 \\
& $(0.201)$ & $(0.137)$ & $(0.927)$ \\
Percentage of GDP spent on & -0.001 & 0.057 & -0.125 \\
health & $(0.988)$ & $(0.768)$ & $(0.517)$ \\
Environmental Health Index & $0.364 *$ & $0.399 *$ & 0.263 \\
& $(0.052)$ & $(0.032)$ & $(0.168)$ \\
\hline \hline
\end{tabular}

Notes: p-values in parentheses; * significant at 0.10 
www.celsi.sk
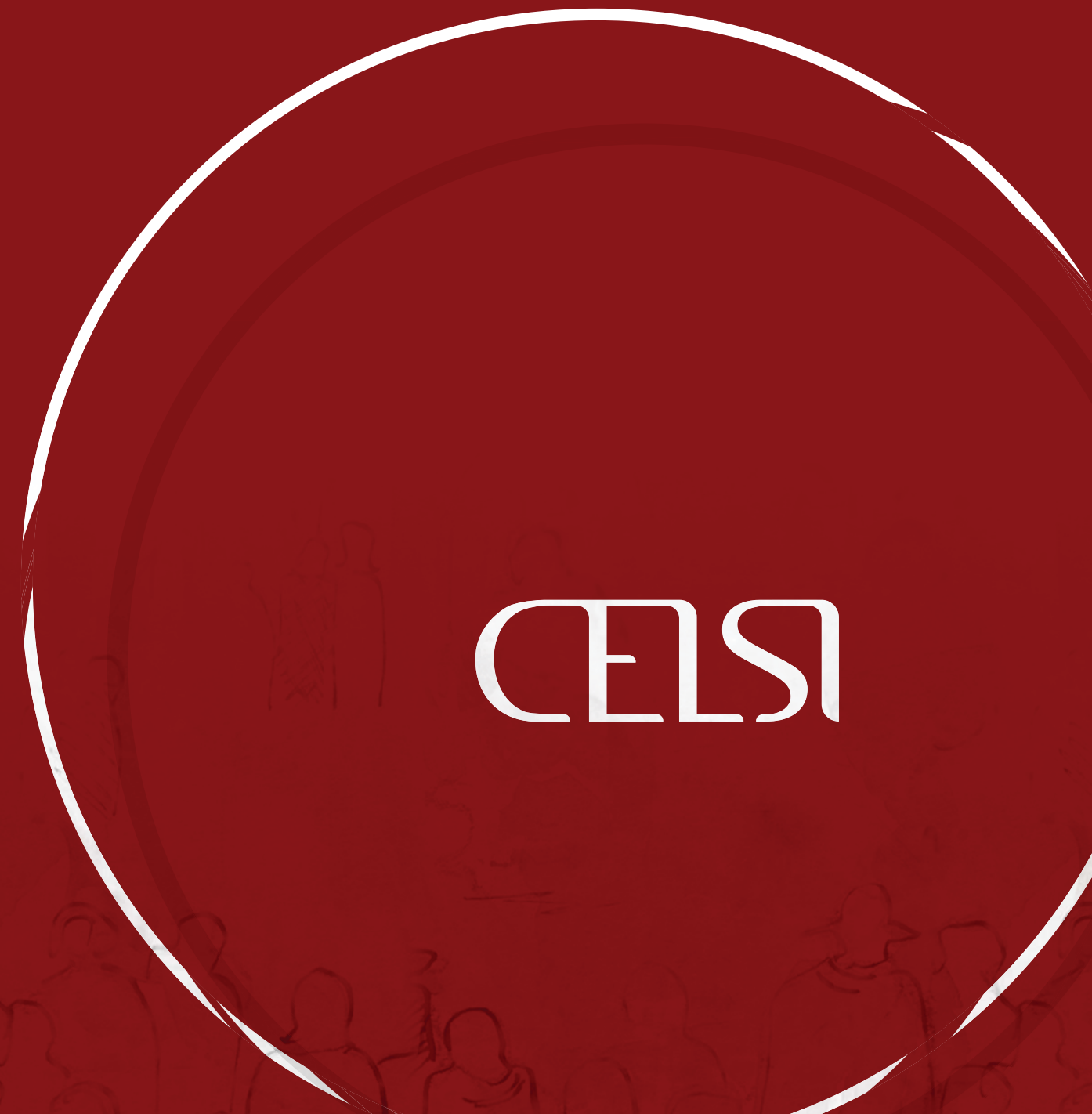